Bentham open

RESEARCH ARTICLE

\title{
Support for the Forensic DNA Database and Public Safety Concerns: An Exploratory Study
}

\author{
Monica Pivetti", Antonella Caggiano, Filippo Cieri, Silvia Di Battista and Chiara Berti \\ Department of Psychological, Health and Territorial Sciences (Di.S.P.U. Ter.) University of Chieti-Pescara, Chieti, \\ Italy
}

Received: February 07, 2017

Revised: February 27, 2017

Accepted: April 20, 2017

\section{Abstract: \\ Background:}

Over the past few decades, 32 European countries have introduced a national DNA database containing samples and/or profiles from suspected/convicted criminal offenders and biological materials from crime scenes. However, only a few studies have empirically investigated opinions on such a practice and the psychosocial factors possibly predicting public support or opposition.

\section{Objective:}

This study aims to preliminarily explore public support for a national DNA database in Italy. In particular, the role played by psychosocial factors, such as concern over individual rights vs. public safety, as well as genetic and juridical/legal literacy in the public's acceptance of a forensic DNA database, was investigated.

\section{Method:}

Within a correlational study, a written questionnaire was administered to a sample $(\mathrm{N}=242)$ of university students.

\section{Results:}

Participants generally showed support for a forensic DNA database. Concerns over public safety predicted the acceptance of a DNA database, with those valuing public safety being more supportive of its implementation, whereas no role was played by familiarity with the fundamental mechanisms of genetics and with the Italian Criminal Code and Criminal Procedure Code.

\section{Conclusion:}

Empirical research on this issue could provide policymakers and the police force with a better picture of the psychosocial factors underlying public support for the DNA database.

Keywords: Forensic DNA database, Public safety concerns, Civil rights, Public support, Genetic literacy.

\section{INTRODUCTION}

Over the past few decades, 32 European countries have introduced a national DNA database containing samples and/or profiles from suspected/convicted criminal offenders and biological materials from crime scenes. As the mobility of people between European countries has become easier over the past decade due to the relaxation of border restrictions between countries, national police forces have started to issue warnings about the ease with which criminal offenders can cross national borders. Therefore, in 1997 the Council of the European Union invited Member States to consider setting up DNA databases, in accordance with the same standards and in a compatible manner. In May 2005,

\footnotetext{
"Address correspondence to this author at the Department of Psychological, Health and Territorial Sciences (Di.S.P.U.Ter.) University of ChietiPescara (Italy), via dei vestini, 66100 Chieti, Italy, Tel: +39 0871 3556592; E-mail: m.pivetti@unich.it
} 
Austria, Belgium, France, Germany, Spain, The Netherlands and Luxembourg underwrote the Prüm Convention, agreeing to exchange data on DNA and fingerprints-and to cooperate against terrorism, cross-border crimes and illegal migration. Member States of the Council of the European Union that did not yet have centralized forensic DNA databases were legally obliged to create them in the future and to make them searchable by other Member States. To date, the Prüm treaty has been ratified by 19 European countries including the UK, Greece, Italy, Portugal and Sweden $[1-5]$.

A great heterogeneity between countries exists with regards the criteria for the entry of a DNA profile, the removal criteria, the search criteria, the removal period, the anonymisation requirement and so on. Two main groups of countries can be identified: countries with legislation classified as having expansive effects (Austria, Denmark, Estonia, Finland, Latvia, Lithuania, Scotland, Slovakia, and England and Wales); countries with legislation classified as having restrictive effects (Belgium, France, Germany, Hungary, Ireland, Italy, Luxemburg, The Netherlands, Poland, Portugal, Romania, Spain and Sweden). In the group of countries whose legislation is considered to have restrictive effects, the condition generally imposed for the inclusion of profiles in databases is that an individual is suspected or convicted of a crime that involves a potential or effective prison sentence, or the fact that the individual subjected to collection of a biological sample has committed crimes that are considered serious. In the expansive group, the inclusion criteria in most countries allow individuals suspected of any crime to be subjected to sample collection and, consequently, to the inclusion of their DNA profiles in the forensic database [4].

\section{THE NATIONAL FORENSIC DNA DATABASE IN ITALY}

With the adoption, on 30 June 2009, of Law No. 8548 "DNA Databank Law", which ratified the Prüm Treaty, the Italian government established the legal basis for the creation of a National DNA Database and connected central laboratory. According to Article 9 Section (1), samples may be taken from persons held in pre-trial detention or under house arrest, persons arrested in flagrante delicto or detained on suspicion of murder, and convicts serving a fixed-term prison sentence for a premeditated crime or who are otherwise subject to custody on a provisional or permanent basis. The scope is also restricted to suspects or convicted offenders of crimes of a certain gravity. For this reason, Article 9 Section (2) specifically excludes the processing of data or biological samples for non-violent crimes, such as fraud or financial crimes. Samples of persons subject to conviction for a period of less than three years will not be mandatory according to Article 24 [6] [7]. In Italy, the DNA database law has been criticized as it does not go into much detail about certain technical and administrative matters pertaining to the management of samples and data, whereas experts stress the importance of more detailed and technical rules [6 - 8].

As for media coverage, in April 2014, several social issue advertisements were broadcast on Italian state television, sponsored by the Italian National Committee for Biosecurity and Biotechnology. The advertisements provided some general information on DNA and described the advantages of a national DNA database. They were aimed at fostering a positive attitude towards databases [9].

After some setbacks due to the current economic crisis, in June 2016 the implementing regulations were published and the National DNA database was established in Italy, with the first sample collected from an inmate at the Regina Coeli State Prison in Rome [10,11].

The Italian NGO Fondazione Diritti Genetici raised some concerns over the protection of individuality and individual rights after the implementation of the DNA database [12]. With the exception of this NGO, there was no public discussion on the issue either before or during the debate of this law.

\section{PUBLIC SUPPORT}

In Europe, the broad implementation of DNA databases has fuelled a range of critical commentaries on their social and ethical significance and consequences [13 - 15]. In our opinion, a set of comments to forensic DNA typing is based on the distinction between the protection of public interest (e.g. the database can help the police carry out fast and reliable identification of crime suspects) and the protection of individual rights (e.g. the database infringes privacy rights by allowing the storage and use of tissue samples and/or profiles). This dualism is reminiscent of the distinction between two models of the criminal justice system: crime control, namely to secure public order and guarantee public security, and due process, namely to protect individual rights and liberties [16 - 20].

With regard to the crime control model, policymakers, criminal investigators and legal professionals have been able to outline a series of benefits stemming from the growing use of this technology, including: the potential to make swift 
as well as thorough suspected offender identifications via automated profile comparisons; the ability to remove innocent suspects from inquiries; the increased likelihood of generating reliable and persuasive evidence for use in court; a reduction in the cost of many investigations; the likely deterrent effect of DNA databasing on potential criminal offenders such as sex offenders; and a possible increase in public confidence in policing and in the judicial process as a whole $[4,21,22]$.

As for the due process model, the collection, storage, and use of DNA samples and profiles raise a number of ethical and social concerns; the threat to the bodily integrity of citizens who are potentially subject to forced sampling of their genetic material; the intrusion of privacy rights caused by the storage and use of tissue samples; the potential for future misuse of such samples held in State and privately-owned laboratories; the potential disclosure of the presence/absence of genetic links between individuals through familial searching in forensic investigations [23 - 27]. Other risks reported in the bioethical and socio-legal literature are the greater risk of social stigmatization and racial stereotyping attributed to the overrepresentation of specific social and ethnic groups in forensic DNA databases [28] and mistaken identification and wrongful conviction resulting from erroneous interpretations of the information provided by DNA profiles [29].

Generally speaking, the aim of safeguarding the public interest clashes with the protection of individual rights. For instance, in recent years, the measures adopted by States to fight terrorism have often posed serious challenges to human rights and the rule of law [30].

As for public perception of DNA databases in the general population, some researchers found that the majority (79.9\%) of the surveyed Spanish population agreed with the possibility of storing the DNA profiles of re-offenders found guilty of committing crimes against the lives, bodily integrity and security of citizens. The public was able to distinguish between different degrees of inclusiveness of the DNA database. Specifically, when the interviewees were asked about the necessity for a national database that includes the forensic DNA analyses and samples of all citizens without having previously obtained their consent, only $42.6 \%$ agreed. On the other hand, opposition decreased to $47.6 \%$ (versus $42.3 \%$ who considered such a measure acceptable) when the surveyed population was consulted about the need to create a national database, for forensic use, of specific groups of non-consenting individuals who repeat the same offence, of whatever nature or gravity. Group differences were observed between professional groups. The weakest opposition was found among professionals working in local or state security, while the strongest opposition was found among legal professionals [31]. Along the same lines, in a simulation study, it was found that threequarters of Portuguese respondents agreed to voluntarily donate a sample for profiling and inclusion in the National Forensic DNA Database. Concerns about the risks of consenting to the donation of a sample for genetic profiling and inclusion in the National Forensic DNA Database are mostly related to lack of control and insufficient or unclear regulations concerning the safeguarding of individuals' data and the supervision of access to and use of genetic data [32, 33]. Similarly, a high acceptance rate was also found in a Swiss sample, showing that forensic use of DNA profiling is considered highly trustworthy [34].

Brewen and Ley [35] studied the role played by the media in shaping the public's perception of DNA evidence, given the abundance of portrayals on popular entertainment television programs, such as the television series "CSI: Crime Scene Investigation", depicting a team of forensic scientists who frequently use DNA evidence to solve crimes. Crime television viewers were positively and significantly related to perceptions of DNA evidence as reliable, but not to support for a national DNA database. Moreover, Ley, Jankowski and Brewer [36] found that the dominant message in CSI was that DNA testing is common, rapid, reliable, and instrumental in solving cases. As a consequence, it often played a crucial role in the criminal investigations portrayed on the show. Some scholars have pointed to the so-called "CSI effect", implying the possible influence of the TV series on the decisions of juries in criminal trials by placing more weight on the forensic evidence produced using DNA testing rather than on other kinds of evidence [22, 37, 38].

Regarding the relationship between scientific literacy and attitudes towards biotechnology, since the 1960s the field of study called Public Understanding of Science (PUS) has investigated the relationship between accuracy of scientific knowledge and acceptance of new science and biotechnology. A common idea is that scientific literacy could help people to make decisions based on solid knowledge and understanding of the subject and, as a consequence, more inclined toward science and scientific research [39, 40]. This position has been criticized for representing the public as "lacking scientific literacy", and thus named "Deficit Model". However, the results obtained through empirical research are somewhat contradictory, with many studies pointing to a weak correlation between knowledge of scientific facts and a positive attitude to science [41 - 43]. To our knowledge, the relationship between genetic literacy and support for a DNA database has not yet been empirically explored. 
Some people see DNA evidence as the ultimate crime-fighting tool, while others remain strongly sceptical. While many researchers from social sciences have debated both sides of the issue [15, 25, 44], only a few studies have empirically investigated opinions on such a practice and the psychosocial factors possibly predicting public support or opposition. For instance, concerns over public safety could lead to a stronger acceptance of the extension of the DNA database, as some believe that crime should be fought by introducing more security, if necessary at the expense of civil rights [45].

\section{AIMS AND HYPOTHESES}

Given the scarcity of studies on the public perception of a forensic DNA database, this study is aimed at the preliminary investigation of the level of general acceptance of a DNA database within a sample of Italian university students. Moreover, it aims to examine the role played by factors such as: concern for individual rights or public safety; scientific literacy on genetics and a basic understanding of Italian criminal law; and public acceptance of forensic DNA databases $[17,18,31,32]$. In this respect, we have formulated the following hypotheses:

$\mathrm{H}_{1}$. Scientific literacy on genetics relates to public opinion on the Italian DNA database law [39 - 41]. As stated before, the relationship between genetic literacy and support for DNA databases has not yet been empirically investigated. Therefore, we predict that support for DNA databases is grounded on sound genetic literacy. According to the PUS field of study, scientific literacy is a prerequisite for effective democratic participation in science and for support for a given technology [46, 47].

$\mathrm{H}_{2}$. Knowledge of criminal law predicts the opinion on the Italian law concerning the forensic DNA database [24, 48]. We predict that opposition to the forensic DNA database is grounded on a basic knowledge of the Italian Criminal and Criminal Procedure Code [31].

$\mathrm{H}_{3}$. The relative importance of the two functions of criminal justice relate to the acceptance of the Italian law on the forensic DNA database, in that $\left(\mathrm{H}_{3 \mathrm{a}}\right)$ those valuing public safety will be more in favour of the DNA database, while $\left(\mathrm{H}_{3 \mathrm{~b}}\right)$ those more in favour of protecting individual rights will oppose the national DNA database [18, 19].

\section{INSTRUMENTS}

Within a correlational study, a written questionnaire ${ }^{\mathrm{i}}$ was administered to a sample of university students. Participants were asked to answer a questionnaire, which included four sections:

- Acceptance of the Italian law on the forensic DNA database. Eleven items measured public support for different aspects of the Italian law on the forensic DNA database (i.e. general acceptance of the law). These items summarize the main issues of the Italian law on the DNA database and were developed by the research team after careful examination of the law's dictates (e.g. "Taking DNA samples from the crime scene"; "Taking samples from people caught in the act, even without their consent"). Participants rated each item on a 7-point Likert scale, from 1 ("totally unacceptable") to 7 ("totally acceptable"). A mean score for the 11 items measuring the acceptance of the DNA databank law was computed.

- Knowledge of Italian criminal law. Twelve items were developed to assess the participants' current basic level of knowledge of some general provisions of Italian criminal law (e.g., "when can a crime be said to be premeditated?"; (a) When there is premeditation and awareness in performing the event; (b) When the event is the result of negligent behaviour; (c) When the event is more serious than at first intended; (d) When the offence is intentional (True)).

Scores were computed by adding up the correct answers (scale ranging from $0=0$ correct answers; to $12=12$ correct answers). Four response options were provided. Only one was correct. These items were selected from a list of questions that legal practitioners can use to prepare for professional examination, and are available on-line [49].

- Scientific Literacy on Genetics. Twelve items were developed to assess the participants' level of scientific literacy on human genetics (e.g., "If a person eats genetically modified fruit, his/her genes could be modified as a result (F)"; "Homozygote twins can be of different sex (F)").

${ }^{\mathrm{i}}$ The questionnaire is provided as supplementary material.

${ }^{\text {ii } T h a n k s ~ a r e ~ d u e ~ t o ~ t h e ~ a t t o r n e y ~ M o n i c a ~ G a l a s s o ~ f o r ~ h e r ~ h e l p ~ i n ~ c o r r e c t l y ~ u n d e r s t a n d i n g ~ t h e ~ l e g a l ~ n o r m s . ~}$ 
Two options were provided, only one of which was correct. Scores were computed by adding up the correct answers (scale ranging from $0=0$ correct answers; to $12=12$ correct answers). Those items were selected from those used in the Eurobarometer 64.3 and from a list of questions used in the university exams on human genetics [50 - 54].

- Functions of criminal justice: public safety vs. individual rights. The importance of the functions of criminal justice was rated on a 7-point Likert scale (7 items on public safety, e.g. "To fight crime", "To secure public order"; 3 items on individual rights, e.g. "to guarantee citizens" equality before the law", "To guarantee civil rights and liberties", from $1=$ not important at all, to 7 = extremely important). The items were selected from a list of items validated in previous research on the functions of criminal justice [19]. A mean score was computed for the seven items on concerns over public safety and for the three items on concerns over individual rights.

Basic socio-demographic information was obtained from each participant, including age, sex, education, year of study, field of study and political orientation.

\section{SAMPLE}

The sample included 242 participants (61 men, 177 women, 4 missing $)$, mean age $=24.6(S D=2.87 ;$ range $16-34)$, enrolled in two public universities in central-northern Italy, divided as follows:

- 90 participants $(37.2 \%)$ from psychology courses;

- 71 participants $(29.3 \%)$ from architecture courses;

- 81 participants $(33.5 \%)$ from law courses.

Students were approached during classes by a research assistant and asked to fill in the questionnaire after a lecture. Participation in the study was on a voluntary basis and no extra credits were given for participation. The questionnaire took approximately 30 minutes to complete. The research method complies with the norms of the Code of Ethics of the Italian Psychology Association [55].

The sample included students of law, psychology and architecture. We carried out this recruitment based on the following reasoning. Students from law courses might be representative of the forensic community they will one day belong to and be more interested in new technologies such as DNA profiling, in terms of the role such scientific evidence can play in court trials. Hence, they could represent opinion from a legal standpoint. Psychology freshers and sophomores earn 10 compulsory credits in biology and genetics and, as a consequence, are characterized by a wider literacy in genetics than law and architecture students. Architecture students can be seen as representative of the average high school graduate in Italy as they have no specific knowledge of law or genetics.

\section{RESULTS}

Preliminary Analysis and Support for an Italian forensic DNA database

The data were analysed using SPSS software [56]. As for acceptance of forensic DNA law, Cronbach's alpha was computed to assess the internal reliability of the measure. The same applies to concern over public safety and concern over civil rights. Results are reported in Table (1). Both measures for acceptance of forensic DNA law and for concern over public safety displayed good values of alpha, ranging from .70 to .79. Cronbach's alpha for Concern over civil rights was acceptable (.59) [57].

Table 1. Internal consistency scores and the correlations between study measures.

\begin{tabular}{|c|c|c|c|c|c|}
\hline & 1. & 2. & 3. & 4. & 5. \\
\hline 1. Acceptance of forensic DNA law & 1 & & & & \\
\hline 2. Knowledge of the Italian Criminal Code & $-.13 *$ & 1 & & & \\
\hline 3. Scientific Literacy on Genetics & .05 & -.01 & 1 & & \\
\hline 4. Concerns over public safety & $.13^{\mathrm{A}}$ & -.10 & -.03 & 1 & \\
\hline 5. Concerns over civil rights & .02 & -.02 & -.04 & $.57 * *$ & 1 \\
\hline Mean & 5.26 & 8.28 & 8.39 & 6.48 & 6.75 \\
\hline$S D$ & .80 & 2.56 & 1.64 & .63 & .47 \\
\hline Cronbach's $\alpha$ & .71 & - & - & .79 & .57 \\
\hline
\end{tabular}

Note: $* p<.05 ;{ }^{* *} p<.01 ;^{A}=.051$

Given the good internal reliability of the scale on the acceptance of the DNA database law $(\alpha=.71)$, a mean score 
was computed. Distribution of answers is reported in Figure 1. Negative values of skewness $(=-1.303)$ indicate a pileup on the right, while positive values of kurtosis $(=3.56)$ indicate flat and light-tailed distribution. The one-sample t-test on the mean score on acceptance of the Italian forensic DNA database revealed that the mean was different from the average point of the response scale, that is four $(t(241)=24.39, p<.001)$, showing that respondents supported the law on the DNA database $(M=5.26, M d n=5.36, S D=.80$, range $1-7)$.

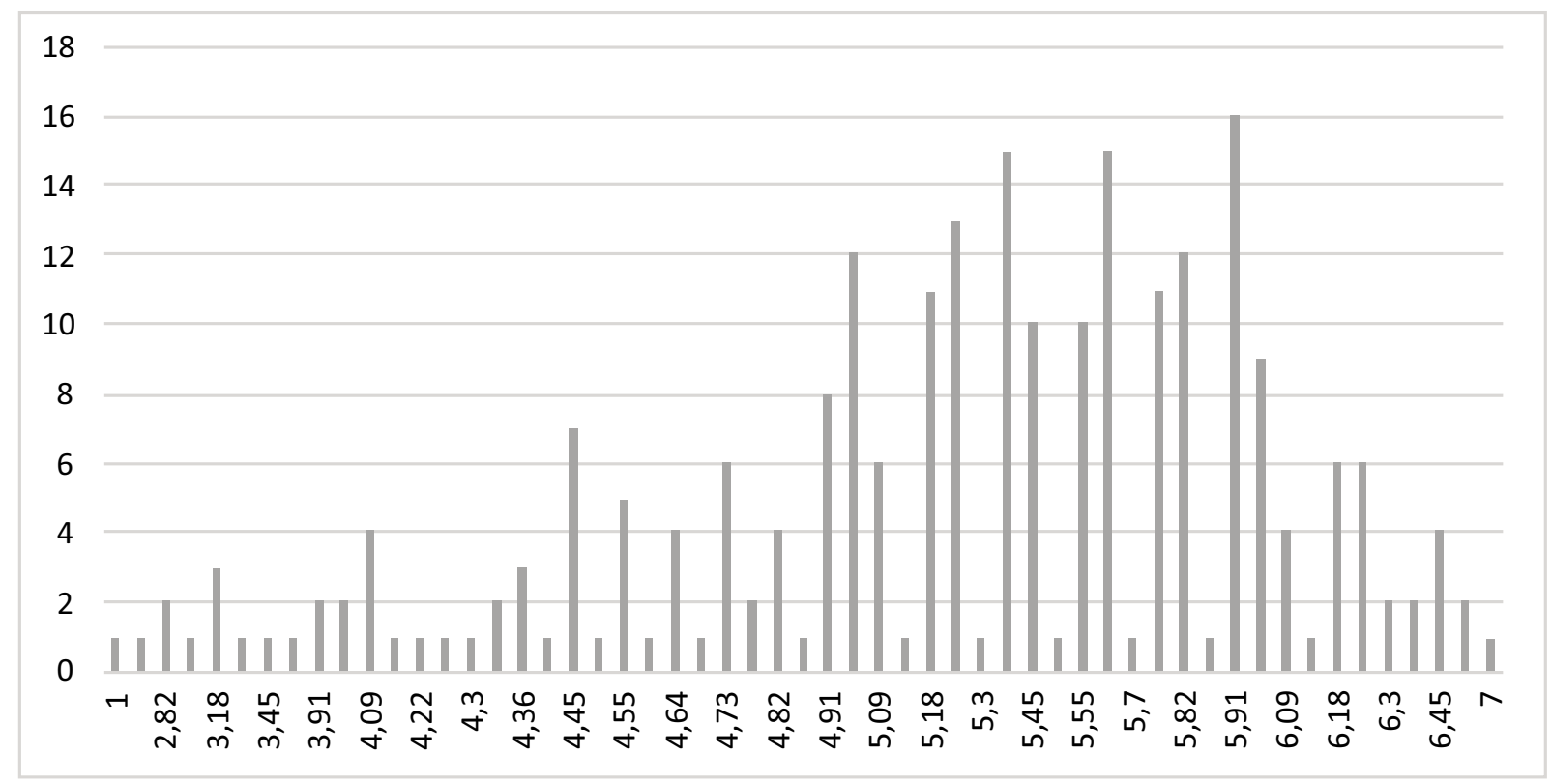

Fig. (1). Distribution of the scores for the acceptance of the DNA database law index.

As for knowledge of the Italian Criminal Code, the percentage of correct answers to each item is displayed in (Fig. 2).

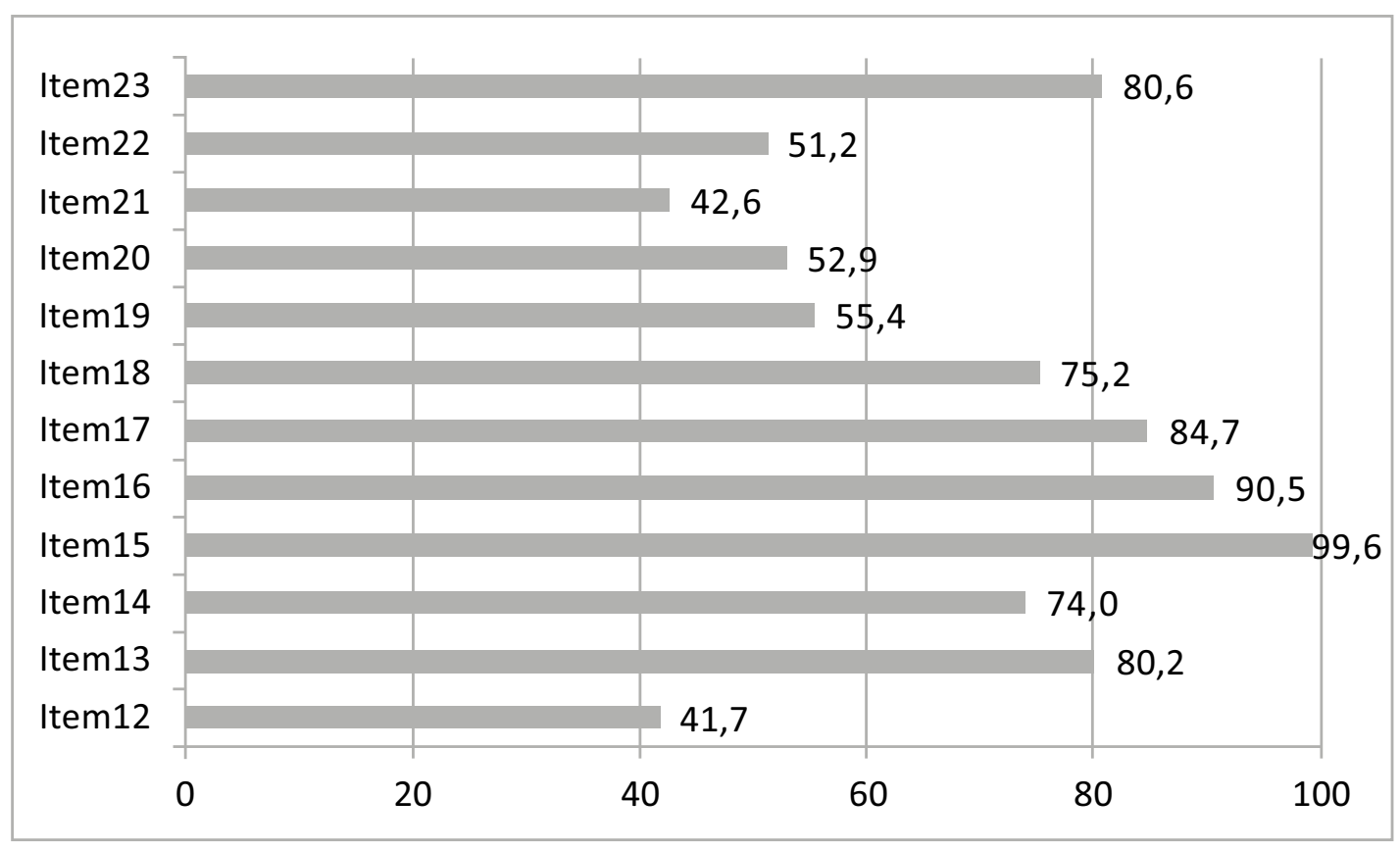

Fig. (2). Percentage of correct answers to the items belonging to the knowledge of the Italian Criminal Code index. 
A cumulative score was computed by adding up the correct answers (scale ranging from $0=0$ correct answers; to 12 $=12$ correct answers). Participants were generally familiar with the Italian Criminal Code, as $75.2 \%$ provided more than seven correct answers out of $12(M=8.29, M d n=8, S D=2.56$, range $3-12)$.

As for scientific Literacy on Genetics, the percentage of correct answers to each item is reported in (Fig. 3).

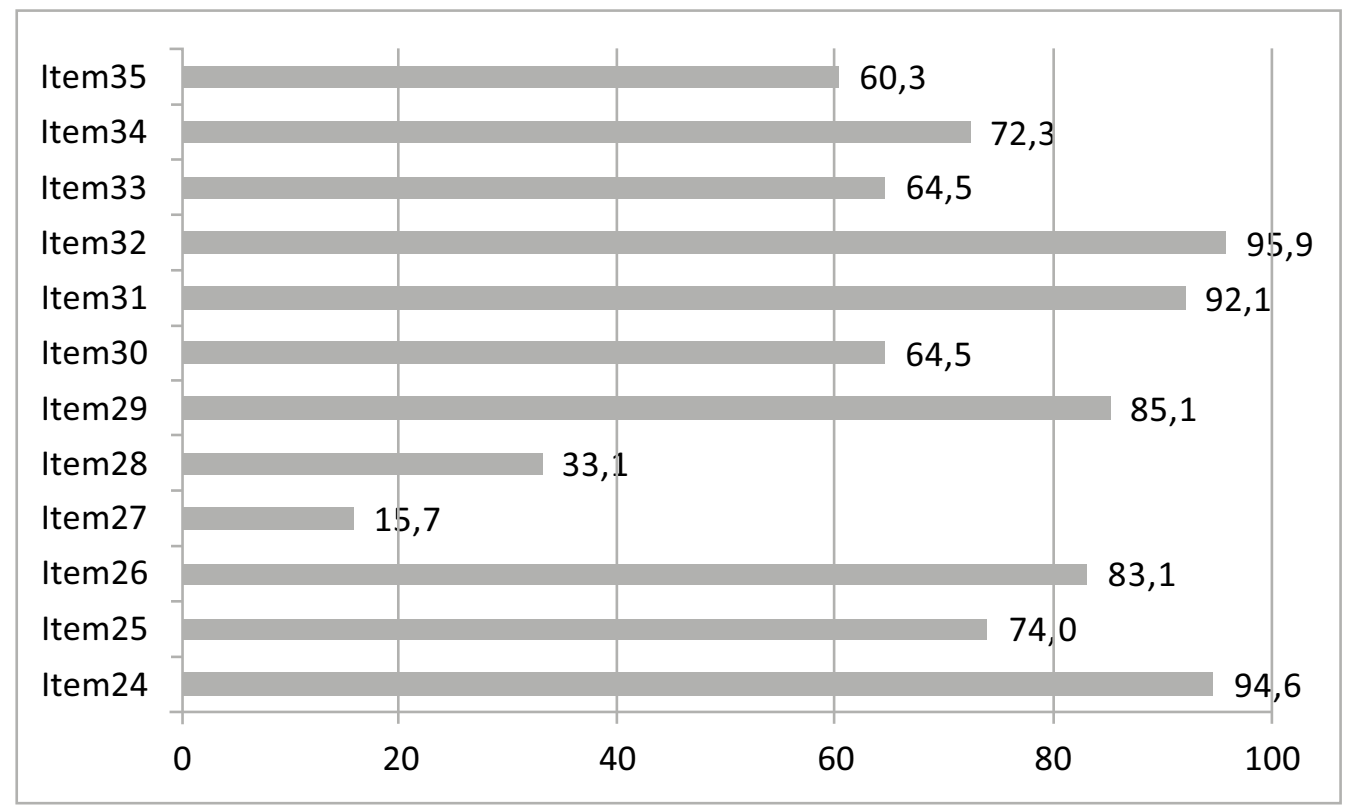

Fig. (3). Percentage of correct answers to each item belonging to the scientific literacy on genetics index.

A cumulative score was computed by adding up the correct answers (scale ranging from $0=0$ correct answers; to 12 $=12$ correct answers). Participants were generally familiar with fundamental mechanisms of genetics, as $86.3 \%$ of them provided more than seven correct answers $(M=8.39, M d n=8, S D=1.64$, range 4 - 12).

As for concern over public safety, a mean score was computed given the good internal reliability of the scale $(\alpha=.79)$. Distribution of the scores is reported in Figure. 4. Negative values of skewness $(=-1.75)$ indicate a pile-up on the right, while positive values of kurtosis $(=3.59)$ indicate flat distribution. The one-sample t-test on the mean score on concern over public safety revealed that the mean was different than the average point of the response scale, that is four $(t(241)=61.35, p<.001)$, showing that participants were concerned over public safety $(M=6.48, M d n=6.71, S D=$ $.63)$.

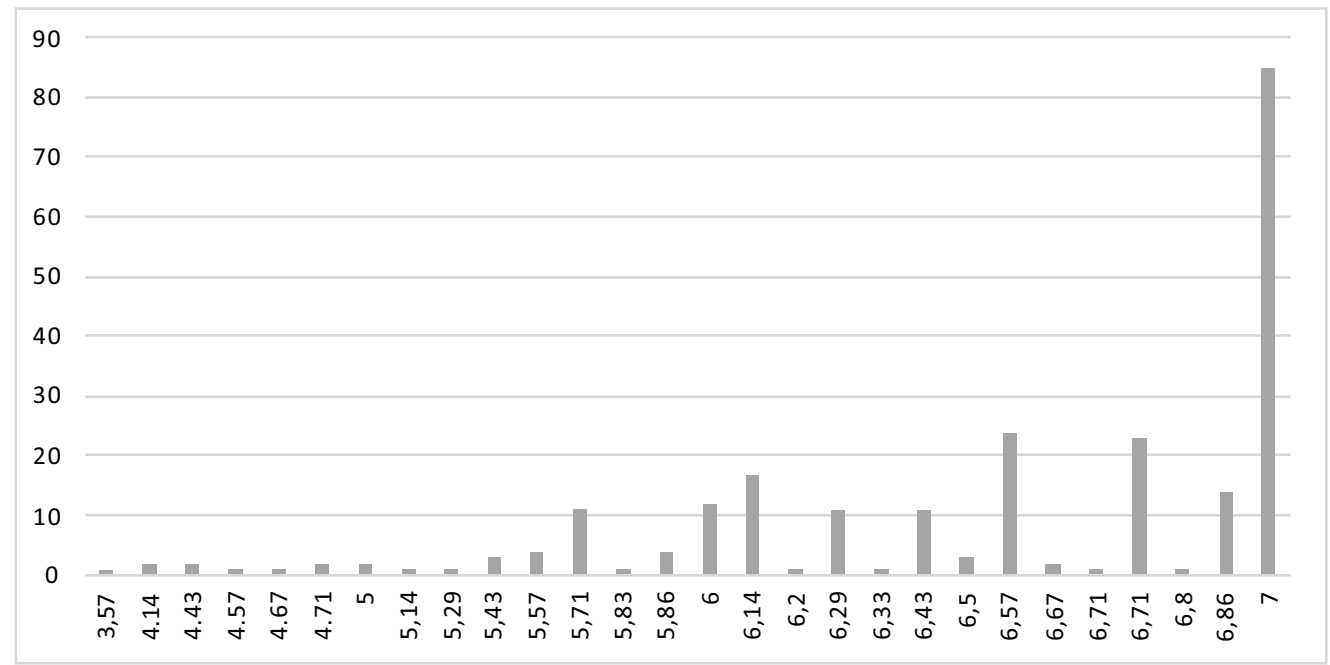

Fig. (4). Distribution of the scores for concern over public support index. 
As for concern over individual rights, a mean score was computed and the distribution of the scores is reported in Figure 4. Negative values of skewness $(=-2.77)$ indicate a pile-up on the right and high positive values of kurtosis $(=$ 9.88 ) indicate a pointy and heavy-tailed distribution. Again, a one-sample t-test on the mean score revealed that the mean was different than the average point of the response scale, that is four $(t(241)=90.02, p<.001)$. Participants were concerned over individual rights $(\mathrm{M}=6.75, M d n=7, S D=.48)$.

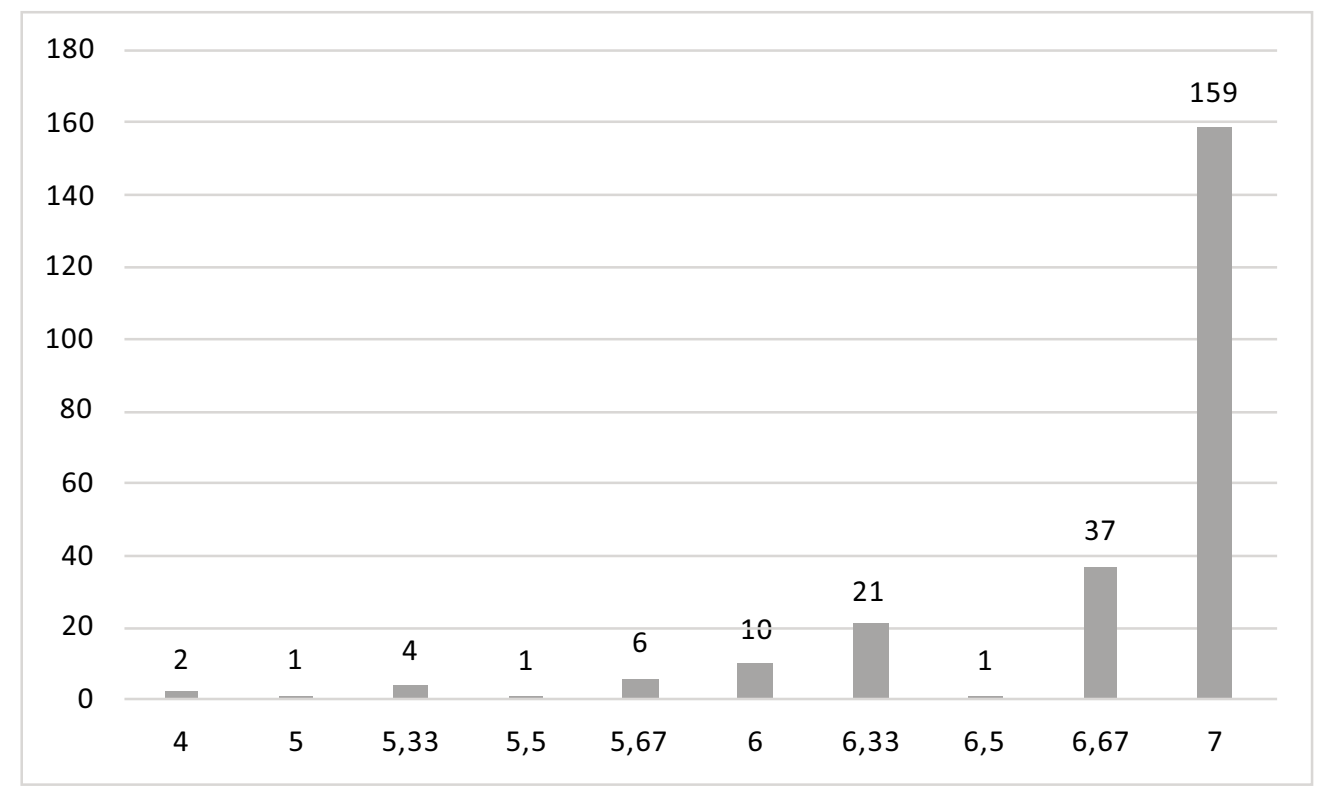

Fig. (5). Distribution of scores for the concern over individual rights index.

Descriptive statistics, reliabilities, and correlations between the study measures are shown in Table (1). Pearson's correlation coefficient $(r)$ lies between -1 and +1 . A coefficient of +1 indicates a perfect positive correlation, a coefficient of -1 indicates a perfect negative relationship, and a coefficient of 0 indicates no linear relationship at all. Values of \pm .1 represent a small effect, \pm .3 is a medium effect and \pm .5 is a large effect [56]. In order to test the hypothesis that a correlation is different from 0 , a p-value was calculated for each correlation coefficient $(r)$. Correlation analysis showed that the acceptance of forensic DNA law negatively relates to the level of knowledge of criminal law (.13 ) and positively relates to concern about public safety (.13), with those in favour of the DNA database being less informed about the Criminal Code and more concerned about public safety. Concern about individual rights and about public safety were positively associated (.57), with those concerned about the protection of individual rights also being concerned about public safety.

A few ANOVAs were conducted to investigate group differences by field of study. There was a significant field of study effect in support of the DNA database $\left(F(2,238)=12.12 ; p<.001 ; M_{\text {Law_students }}=5.03, M_{P_{\text {sychology_students }}}=5.31\right.$; $\left.M_{\text {Architecture_students }}=5.58\right)$. The Bonferroni post-hoc test revealed that psychology students were more supportive than law students $(p=.022)$, while architecture students were more supportive than law and psychology students $(p<.001$ and $p$ $=.053$, respectively).

A significant effect of the study field was found on the level of knowledge of the Criminal Code $(F(2,238)=$ 182.69; $\left.p<.001 ; M_{P}^{\mathrm{iii}}=6.80, M_{A}=6.99 ; M_{L}=11.09\right)$. Unsurprisingly, law students were more familiar with the Criminal Code than psychology and architecture students $(p s<.001)$.

Field of study had an effect on genetic literacy $\left(F(2,238)=9.24 ; p<.001 ; M_{L}=8.01, M_{A}=8.09 ; M_{P}=8.97\right)$. Law and architecture students were less literate in genetics than psychology students $(p<.001$ and $p=.002$, respectively).

Finally, differences also emerged with regard to concerns over public safety $\left(F(2,238)=5.34 ; p=.005 ; M_{L}=6.30\right.$, $\left.M_{P}=6.55 ; M_{A}=6.59\right)$. Law students were less concerned about public safety than psychology and architecture students $(p=.008$ and $p=.003$, respectively).

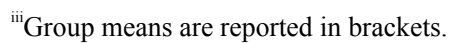




\section{Predictors of Opinion on the Forensic DNA Database}

A series of hierarchical regressions was used to ascertain the relative contribution of Knowledge of the Criminal Code, Scientific Literacy on Genetics, Concerns over public safety and Concerns over civil rights, on the acceptance of the forensic DNA database, above and beyond the field of study effects. In hierarchical regression, predictors are generally selected based on past work and the researcher decides in which order to enter the predictors into the model. Known predictors should be entered into the model first in order of their importance in predicting the outcome. After known predictors have been entered, the experimenter can add any new predictors into the model [56].

We ran the regression analysis on the centred scores. An analysis of standard residuals was carried out on the data to identify that participants 96,99 and 154 had to be removed (standard residual $>|3.29|$ ). The multiple regression models satisfied the assumption of multivariate normality, linearity, independence of errors and homoscedasticity. The hierarchy consisted of three steps: (a) Psychology students, Architecture Students (dummy variables), (b) psycho-social factors: Knowledge of the Criminal Code, Scientific Literacy on Genetics, Concerns over public safety and Concerns over civil rights; (c) interaction term: Concern over individual rights and Psychology students (see Table 2). In order to control for field of study, two dummy variables (Psychology students $=1$; Architecture students=1) were created and entered at the first step of the regression analysis.

In order to interpret multiple regressing, the value of $R^{2}$ is important as it is a measure of how much of the variability in the outcome is accounted for by the predictors. In case of hierarchical regression, attention should be paid to the assessment of the improvement of the model at each stage of the analysis by looking at the change in $R^{2}\left(\Delta R^{2}\right)$ and whether the change is significant. A p-value is calculated for each change in $R^{2}$ [56].

At step 1, the field of study significantly predicted the acceptance of the DNA database, with psychology and architecture students being more supportive than law graduates $\left(R^{2}=.09\right)$. At step 2, when controlling for field of study, concerns over public safety predicted acceptance of the DNA database $(\beta=.19)$ (supporting $\mathrm{H}_{3 \mathrm{a}}$ ), although contribution to the model was limited $\left(\Delta R^{2}=.024\right)$. At step 3 , an interaction effect of concern for civil rights and psychology students revealed that concerned psychology students were more supportive of the DNA database $(\beta=.59)$, while concerned law students were not $\left(\Delta R^{2}=.032\right)$. No other interaction involving the field of study emerged.

In summary, after controlling for field of study, high concerns over public safety were related to support for the establishment of a national DNA database, while no role was played by familiarity with the fundamental mechanisms of genetics (not supporting $\mathrm{H}_{1}$ ) and with the Italian Criminal Code (not supporting $\mathrm{H}_{2}$ ). Moreover, psychology and architecture students were more in favour than law students. As a minor result, concern for the protection of civil rights predicted support for the database only for psychology students (in contrast with $\mathrm{H}_{3 \mathrm{~b}}$ ).

Table 2. Results of Hierarchical Regression Analyses Predicting Acceptance of the Forensic DNA Database.

\begin{tabular}{|c|c|c|c|c|c|c|c|c|c|c|c|c|}
\hline & \multicolumn{4}{|c|}{ Step 1} & \multicolumn{4}{|c|}{ Step 2} & \multicolumn{4}{|c|}{ Step 3} \\
\hline Variable & $B$ & $S E B$ & $\beta$ & $p$ & $B$ & $S E B$ & $\beta$ & $p$ & $B$ & $S E B$ & $\beta$ & $p$ \\
\hline Psychology Students (Psychology =1) & $.29 * *$ & 0.11 & .19 & .008 & .24 & 0.17 & .16 & .158 & .20 & 0.17 & .13 & 247 \\
\hline Architecture students (Architecture $=1$ ) & $.55^{* * *}$ & 0.11 & .35 & $<.001$ & $.52 * *$ & 0.17 & .33 & .002 & $.49 * *$ & 0.16 & .31 & .003 \\
\hline Knowledge of the criminal code & & & & & .01 & 0.03 & .02 & .838 & -.01 & 0.03 & -.02 & .857 \\
\hline Genetic literacy & & & & & .03 & 0.03 & .06 & .959 & .03 & 0.03 & .06 & .345 \\
\hline Concerns over public safety & & & & & $.20 *$ & 0.09 & .17 & .026 & $.19 *$ & 0.09 & .17 & .028 \\
\hline Concerns over civil rights & & & & & -.12 & 0.12 & -.08 & .319 & -.34 & 0.19 & -.22 & .071 \\
\hline Concern over civil rights *Psychology Students & & & & & & & & & $.59 *$ & 0.23 & .24 & .012 \\
\hline$d f$ & & $(2-237)$ & & & & $(6-237)$ & & & & $(8-237)$ & & \\
\hline$F$ & & $12.06 * * *$ & & & & $5.09 * * *$ & & & & $5.01 * * *$ & & \\
\hline$R^{2}$ & & .093 & & & & .117 & & & & .149 & & \\
\hline$\Delta R^{2}$ & & - & & & & .024 & & & & $.032 *$ & & \\
\hline
\end{tabular}

Note: $N=239 ; * p<.05, * * p<.01, * * * p<.001$

\section{DISCUSSION AND CONCLUSION}

This study is a preliminary investigation of public support for the current Italian law on the national DNA database in Italy, among a sample of university students. As a whole, participants support the law's dictates, as broken down into 
a set of items by the researchers. This is in line with research by Wilson-Kovacs, Wyatt \& Hauskeller [58], who compared different uses of genetic technologies and found that forensic DNA was the least problematic of genetic applications in the UK. Also, some scholars found wide support for a National Forensic DNA Database in England, Wales, Spain and Portugal [31, 59, 60].

As for the psycho-social determinants affecting participants' support, concern for public safety predicts the acceptance of the DNA database. Our data confirm that the implementation of a DNA database is related to concerns over the protection of society in general (supporting $\mathrm{H}_{3 \mathrm{a}}$ ), with those valuing public safety being more supportive of the DNA database. This is in line with the common sense knowledge that the availability of a DNA database could provide police forces with an important crime-solving tool [61]. This is also consistent with the message conveyed by fictional TV dramas on the importance of high-technology science to fight crimes and ensure offenders are brought to justice $[36,62]$.

Finally, concerns about protection of civil rights predicted support for the database by psychology students alone (in contrast with $\mathrm{H}_{3 \mathrm{~b}}$ ). One possible explanation is that psychology students have a specific conception of the means for protecting individual rights, given the socialization process with regard to ethical principles in professional practice they experience while attending university. For psychology students, implementation of the DNA database is instrumental in safeguarding individual rights, which is definitely not in contrast with the protection of the interests of society.

With regard to knowledge of the Italian Criminal Code, our results disconfirm our expectation that greater knowledge would lead to stronger support for the DNA database in two ways. On one hand, regression analysis showed that no role was played by familiarity with the Italian Criminal Code in supporting the DNA database (not supporting $\mathrm{H}_{2}$ ). On the other hand, law students were less supportive of the DNA database than any other study group. In contrast with $\mathrm{H}_{2}$, being more familiar with the Italian criminal justice system was related to weaker support for the DNA database, in line with the results found in Spain by Gamero and colleagues [31]. Some experts in forensic science have raised concerns on DNA profiling, regarding the protection of privacy and the risk of becoming a nation with unfettered police powers (in Italy [9, 48]; in the USA [24, 63],). In other words, in the case of a forensic DNA database, the balancing of public safety and privacy concerns may lean toward the protection of society, through government intrusion in the private sphere of individuals. This balancing is specifically relevant to law students as it lies at the heart of-their socialization process, leading to the acquisition of a full professional identity [64].

Given the lack of specific studies on the relationship between genetic literacy and support for the forensic DNA database, we have turned to the studies investigating the connection between scientific knowledge and support for science and genetics. A number of studies have found a positive relationship between scientific knowledge and attitude toward science in the general public $[41,65,66]$. However, contrary to expectations $\left(\mathrm{H}_{1}\right)$, in our study scientific literacy in genetics is unrelated to opinions on the DNA database. This is consistent with several studies criticizing the Public Understanding of Science (PUS) field of study, showing that the level of knowledge of a given technology does not directly relate to support for such technology [39, 40]. The contextualist approach to the PUS adds to this debate by reflecting on the role played by the forms of institutional embedding of scientific knowledge. For instance, claims made by government experts may be evaluated differently to those made by scientists employed by non-governmental organizations [67]. In this sense, low confidence in scientific expertise and in the institutional arrangements under which expertise is authorized and managed might influence public attitudes in conflicting ways vis-à-vis the content of scientific knowledge. Future research should investigate how confidence in formal scientific knowledge validated by the scientific method and confidence in the practical implementation of a new technology, such as the DNA database, by public institutions could affect attitudes towards said DNA database [68, 69]. However, as participants may understand fundamental genetic law, but don't understand the methods of working with the DNA database, future research should use more specific measures of the participants' understanding of the DNA database.

The limitations of the study are mainly due to the student sample. Even though the inclusion of students from different fields of study can contribute to revealing some of the psychosocial determinants of public support for the DNA database, a larger randomly selected sample is recommended to ensure generalisability. We are aware of the preliminary nature of the study, which can only provide some clues for the understanding of those psychosocial factors underlying support for the DNA database in Europe.

Given the lack of public debate on the issue, psychosocial research into public acceptance of the DNA database is especially important to foster public engagement and to discover what people have to say about the use of genetic information and the way crime is fought and offenders prosecuted in the society they live in. This is especially 
important as a result of the criticisms levelled against the DNA database law. Empirical research into the issue could provide policy-makers, police forces, lawyers of civil rights groups and associations for the protection of genetic materials with a clearer picture of public opinions on the DNA database.

\section{ETHICS APPROVAL AND CONSENT TO PARTICIPATE}

Not applicable.

\section{HUMAN AND ANIMAL RIGHTS}

No Animals/Humans were used for studies that are base of this research.

\section{CONSENT FOR PUBLICATION}

Not applicable.

\section{CONFLICT OF INTEREST}

The authors declare no conflict of interest, financial or otherwise.

\section{ACKNOWLEDGEMENTS}

Declared none.

\section{REFRENCES}

[1] ENFSI. ENFSI survey on DNA databases in Europe. Available from: (http://www.enfsi.eu/ sites/default/files/ documents/enfsi_survey_on_dna_databases_in_europe_december_2015_final_0.pdf). 2016. Accessed on January 18, 2017

[2] Martin PD, Schmitter H, Schneider PM. A brief history of the formation of DNA databases in forensic science within Europe. Forensic Sci Int 2001; 119(2): 225-31.

[http://dx.doi.org/10.1016/S0379-0738(00)00436-9] [PMID: 11376988]

[3] Johnson P, Williams R. Internationalizing new technologies of crime control: Forensic DNA databasing and datasharing in the European Union. Policing Soc 2007; 17(2): 103-18. [http://dx.doi.org/10.1080/10439460701302669]

[4] Santos F, Machado H, Silva S. Forensic DNA databases in European countries: Is size linked to performance? Life Sci Soc Policy 2013; 9: 12. [http://dx.doi.org/10.1186/2195-7819-9-12]

[5] Council of the European Union. Treaty Prüm Available from (http://registerconsiliumeuropaeu/pdf/en/05/st10/st10900en05pdf 2005. [Accessed on: $18^{\text {th }}$ January 2017].

[6] CELAB (Center for Ethics and Law in BioMedicine). The legal regulation of biobanks. National report: Italy. CELAB Paper series. Report number: 10, 2010. Available from: (http://mespom.eu/node/12952). 2010. [Accessed 18th January 2017]

[7] Biondo R, De Stefano F. Establishment of Italian national DNA database and the central laboratory: Some aspects. Forensic Sci International Genet Suppl Ser 2011; 3(1): e236-7.

[http://dx.doi.org/10.1016/j.fsigss.2011.08.117]

[8] Monti A. Italian DNA database: The devil is in the details. Available from: (http://history.edri.org/edri-gram/number7.16/dna-database-italy) 2009. [Accessed on: 18 January 2017]

[9] Social interest commercials on DNA databank broadcast on national channels. $4^{\text {th }}$ February 2014] Available from: https://www.youtube.com/watch?v=wCtEs7bJ51w 2009. [Accessed 18th January 2017]

[10] Ribaudo A. Al via la Banca dati nazionale sul DNA. [16th June 2016] Available from: (http://www.corriere.it/ cronache/16_giugno_16/al-viabanca-dati-nazionale-dna-1d7e2912-3386-11e6-b8e9-6b78a4af30ec.shtml?refresh_ce-cp 2009. [Accessed on: 18 ${ }^{\text {th }}$ January 2017]

[11] Bronzo E. Dna, dal 10 giugno una banca dati per trovare criminali e persone scomparse. Il Sole 24ore. [26 ${ }^{\text {th }}$ May 2016] Available from: (http://www.ilsole24ore.com/art/notizie/2016-05-27/dna-10-giugno-banca-dati-trovare-criminali-e-persone-scomparse-094002.shtml?uuid=A DoLJsQ. [Accessed $18^{\text {th }}$ January 2017]

[12] Fondazione Diritti Genetici. Fondazione Diritti Genetici. Available from: (http://www.fondazionedirittigenetici.org/fondazione/new/) [Accessed on $18^{\text {th }}$ January 2017].

[13] Williams R, Johnson P. Forensic DNA databasing: a European perspective. The Welcome Trust, Interim Report. Report number: 16, Available from: (http://community.dur.ac.uk/robin.williams/EU_Interim_Report_2005.pdf) 2005. Accessed on $18^{\text {th }}$ January 2017

[14] Williams R, Johnson P. Inclusiveness, effectiveness and intrusiveness: Issues in the developing uses of DNA profiling in support of criminal investigations. J Law Med Ethics 2005; 33(3): 545-58.

[http://dx.doi.org/10.1111/j.1748-720X.2005.tb00517.x] [PMID: 16240734] 
[15] Levitt M. Forensic databases: Benefits and ethical and social costs. Br Med Bull 2007; 83(1): 235-48. [http://dx.doi.org/10.1093/bmb/ldm026] [PMID: 17906329]

[16] Toom V. Forensic DNA databases in England and the Netherlands: Governance, structure and performance compared. New Genet Soc 2012; 31(3): 311-22. ISSN: 0263-323X.

[17] Packer H. Two models of the criminal process. Univ Pa Law Rev 1964; 113(1): 1-68. [http://dx.doi.org/10.2307/3310562]

[18] Packer H. The limits of the criminal sanction. Stanford: Stanford University Press 1968.

[19] Berti C, Mestitz A, Palmonari A, Sapignoli M. Social representations of Italian criminal justice: Ideals and reality. In: Social Representations in the 'Social Arena', Routledge. 2012; 113: pp. (1)129-39. ISBN: 978-0-415-59119-5.

[20] Aquilina K. Public security versus privacy in technology law: A balancing act? Comput Law Secur Rev 2010; 26(2): 130-43. [http://dx.doi.org/10.1016/j.clsr.2010.01.002]

[21] Wallace HM, Jackson AR, Gruber J, Thibedeau AD. Forensic DNA databases-Ethical and legal standards: A global review. Egypt J Forensic Sci 2014; 4: 57-63.

[http://dx.doi.org/10.1016/j.ejfs.2014.04.002]

[22] Robert D, Dufresne M. The social uses of DNA in the political realm or how politics constructs DNA technology in the fight against crime. New Genet Soc 2008; 27(1): 69-82.

[http://dx.doi.org/10.1080/14636770701843675]

[23] Murphy E. The Government wants your DNA. Scientific American 2013; 308(3): 72-7. ISSN:0036-8733. [http://dx.doi.org/10.1038/scientificamerican0313-72]

[24] Rothstein MA, Talbott MK. The expanding use of DNA in law enforcement: What role for privacy? J Law Med Ethics 2006; 34(2): 153-64. [http://dx.doi.org/10.1111/j.1748-720X.2006.00024.x] [PMID: 16789940]

[25] Cho MK, Sankar P. Forensic genetics and ethical, legal and social implications beyond the clinic. Nat Genet 2004; 36(11)(Suppl.): S8-S12. [http://dx.doi.org/10.1038/ng1594] [PMID: 15510102]

[26] Maguire CN, McCallum LA, Storey C, Whitaker JP. Familial searching: a specialist forensic DNA profiling service utilising the National DNA Database to identify unknown offenders via their relatives--the UK experience. Forensic Sci Int Genet 2014; 8(1): 1-9. [http://dx.doi.org/10.1016/j.fsigen.2013.07.004] [PMID: 24315582]

[27] Hallinan D, Friedewald M, McCarthy P. Citizens' perceptions of data protection and privacy in Europe. Comput Law Secur Rev 2012; 28: 263-72. [http://dx.doi.org/10.1016/j.clsr.2012.03.005]

[28] Chow-White PA, Duster T. Do health and forensic DNA databases increase racial disparities? PLoS Med 2011; 8(10): e1001100. [http://dx.doi.org/10.1371/journal.pmed.1001100] [PMID: 21990964]

[29] Williams R, Johnson P. 'Wonderment and dread': Representations of DNA in ethical disputes about forensic DNA databases. New Genet Soc 2004; 23(2): 205-23. [http://dx.doi.org/10.1080/1463677042000237035] [PMID: 15460615]

[30] Office of the United Nations High Commissioner for Human Rights. Human Rights, Terrorism and Counter-terrorism. Fact Sheet No. 32. Available from: (https://www.un.org/ruleoflaw/blog/document/human-rights-terrorism-and-counter-terrorism-fact-sheet-no-32/) 2008. Accessed on: $18^{\text {th }}$ January 2017

[31] Gamero JJ, Romero JL, Peralta JL, Carvalho M, Corte-Real F. Spanish public awareness regarding DNA profile databases in forensic genetics: What type of DNA profiles should be included? J Med Ethics 2007; 33(10): 598-604. [http://dx.doi.org/10.1136/jme.2006.016998] [PMID: 17906059]

[32] Machado H, Silva S. "Would you accept having your DNA profile inserted in the National Forensic DNA database? Why?" Results of a questionnaire applied in Portugal. Forensic Sci Int Genet 2014; 8(1): 132-6. [http://dx.doi.org/10.1016/j.fsigen.2013.08.014] [PMID: 24315600]

[33] Machado H, Silva S. Public participation in genetic databases: crossing the boundaries between biobanks and forensic DNA databases through the principle of solidarity. J Med Ethics 2015; 41(10): 820-4. [http://dx.doi.org/10.1136/medethics-2014-102126] [PMID: 26139851]

[34] Zieger M, Utz S. About DNA databasing and investigative genetic analysis of externally visible characteristics: A public survey. Forensic Sci Int Genet 2015; 17: 163-72. [http://dx.doi.org/10.1016/j.fsigen.2015.05.010] [PMID: 26004189]

[35] Brewen PR, Ley BL. Media use and public perceptions of DNA evidence. Sci Commun 2010; 32(1): $93-117$. [http://dx.doi.org/10.1177/1075547009340343]

[36] Ley BL, Jankowski N, Brewer PR. Investigating CSI: Portrayals of DNA testing on a forensic crime show and their potential effects. Public Underst Sci 2012; 21(1): 51-67. [http://dx.doi.org/10.1177/0963662510367571] [PMID: 22530487]

[37] Schweitzer NJ, Saks MJ. The CSI effect: Popular fiction about forensic science affects the public's expectations about real forensic science. Jurimetrics 2007; 47: 357-64. 
[38] Symon V, Heydon S, Medlicott NJ, Kieser J, Fleming JS. Before CSI: Making the case for a novel portrayal of Forensic Science. The Int J Sci Soc 2015; 2007; 6: 7-15. ISSN 1836-6236.

[39] Bauer MW, Allum N, Miller S. What can we learn from 25 years of PUS survey research? Liberating and expanding the agenda. Public Underst Sci 2007; 16(1): 79-95.

[http://dx.doi.org/10.1177/0963662506071287]

[40] Edwards J. Taking ‘public understanding' seriously. New Genet Soc 2002; 21(3): 315-25. [http://dx.doi.org/10.1080/14636770216011]

[41] Allum N, Sturgis P, Tabourazi D, Brunton-Smith I. Science knowledge and attitudes across cultures: A meta-analysis. Public Underst Sci 2008; 17(1): 35-54. [http://dx.doi.org/10.1177/0963662506070159]

[42] Bauer MW, Durant J, Evans G. European public perceptions of science. Int J Public Opin Res 1994; 6(2): $163-86$. [http://dx.doi.org/10.1093/ijpor/6.2.163]

[43] Miller JD. Public understanding of, and attitudes toward, scientific research: What we know and what we need to know. Public Underst Sci 2004; 13: 273-94 [http://dx.doi.org/10.1177/0963662504044908]

[44] Nelkin D, Andrews L. DNA identification and surveillance creep. Sociology of Health \& Illness 1999; 21(5): 689-706. ISSN 0141-9889. [http://dx.doi.org/10.1111/1467-9566.00179]

[45] Grodeland AB. Perceptions of civil rights, security and the "war on terror": East and West compared. Communist Post-Communist Stud 2015; 48: 317-35. [http://dx.doi.org/10.1016/j.postcomstud.2015.10.003]

[46] Durant JR, Evans GA, Thomas GP. The public understanding of science. Nature 1989; 340(6228): 11-4 [http://dx.doi.org/10.1038/340011a0] [PMID: 2739718]

[47] Wynne B. Public understanding of science. In: Jasanoff S, Markle GE, Petersen JC, Pinch T, Eds. Handbook of Science and Technology Studies. Thousand Oaks: Sage 1995; pp. 316-88

[48] Rodotà S. Speech of the President of the Italian Authority for the Protection of Personal data 2004. Available from: (http://194.242.234.211/documents/10160/10704/1093804), [Accessed on: 18 ${ }^{\text {th }}$ January 2017].

[49] Italian Home Office. Exercises to assess the knowledge of Italian Criminal Code, in preparation for open competitive exams. Available from: (http://www.mininterno.net/begint.asp?ida=306.) n.d. [Accessed 18th January 2017]

[50] Catz DS, Green NS, Tobin JN, et al. Attitudes about genetics in underserved, culturally diverse populations. Community Genet 2005; 8(3): 161-72. [http://dx.doi.org/10.1159/000086759] [PMID: 16113533]

[51] Gaskell G, Stares S, Allansdottir A, et al. Eurobarometer 64.3. Europeans and Biotechnology in 2005: Patterns and Trends. Available from (http://ec.europa.eu/public_opinion/archives/ebs/ebs_244b_en.pdf) 2006. [Accessed on 14 ${ }^{\text {th }}$ March 2017].

[52] Pivetti M, Melotti G. Prenatal genetic testing: an investigation of determining factors affecting the decision-making process. J Genet Couns 2013; 22(1): 76-89. [http://dx.doi.org/10.1007/s10897-012-9498-6] [PMID: 22477148]

[53] Pivetti M, Melotti G, Morselli D, Olivieri M. Psychosocial factors affecting uptake of prenatal genetic testing: a pilot study. Prenat Diagn 2013; 33(13): 1276-82. [http://dx.doi.org/10.1002/pd.4248] [PMID: 24122815]

[54] Smerecnik CM, Mesters I, de Vries NK, de Vries H. Educating the general public about multifactorial genetic disease: applying a theorybased framework to understand current public knowledge. Genet Med 2008; 10(4): 251-8. [http://dx.doi.org/10.1097/GIM.0b013e31816b4ffd] [PMID: 18414207]

[55] Associazione Italiana di Psicologia AI. Associazione Italiana di Psicologia, A.I.P. Code of ethics of the Italian Psychological Association. Code of ethics of the Italian Psychological Association. 2000. Available from (http://www.aipass.org/node/26.) 2000. [Accessed on 10 January 2015]

[56] Field A. Discovering statistics using IBM SPSS statistics. Sage 2013.

[57] Tavakol M, Dennick R. Making sense of Cronbach's alpha. Int J Med Educ 2011; 2: 53-5. [http://dx.doi.org/10.5116/ijme.4dfb.8dfd] [PMID: 28029643]

[58] Wilson-Kovacs D, Wyatt D, Hauskeller C. "A Faustian bargain?" Public voices on forensic DNA technologies and the National DNA Database. New Genet Soc 2012; 31(3): 285-98. [http://dx.doi.org/10.1080/14636778.2012.687085]

[59] Stackhouse R, Anderson C, Shaw AM, Iredale R. Avoiding the "usual suspects": Young people's views of the National DNA Database. New Genet Soc 2010; 29(2): 149-66. [http://dx.doi.org/10.1080/14636778.2010.484234]

[60] Machado H, Silva S. Public Perspectives on risks and benefits of forensic DNA databases: An approach to the influence of professional group, education, and age. Bull Sci Technol Soc 2015; 35(1-2): 1-9. 
[http://dx.doi.org/10.1177/0270467615616297]

[61] Hindmarsh R. Australian biocivic concerns and governance of forensic DNA technologies: Confronting technocracy. New Genet Soc 2008; 27(3): 267-84.

[http://dx.doi.org/10.1080/14636770802326935]

[62] Cole SA, Dioso-Villa R. The CSI effect: The true effect of crime scene television on the justice system. New Engl Law Rev 2007; 41 : 435-55.

[63] Murphy E. The new forensics: Criminal justice, false certainty, and the second generation of scientific evidence. Calif Law Rev 2007; 95(3): 721-97.

[http://dx.doi.org/http://dx.doi.org/doi:10.15779/Z38R404]

[64] Mestitz A. Psicologia giuridica e ricerca. Psicologia e Giustizia 2003; 4(1): 1-15.

[65] Marzuillo C, De Vito C, D'Addario M, et al. Are public health professionals prepared for public health genomics? A cross-sectional survey in Italy. BMC Health Serv Res 2014; 14(1): 239.

[http://dx.doi.org/10.1186/1472-6963-14-239] [PMID: 24885316]

[66] Sturgis P, Cooper H, Fife-Schaw C. Attitudes to biotechnology: Estimating the opinions of a better-informed public. New Genet Soc 2005; 24(1): 31-56. [http://dx.doi.org/10.1080/14636770500037693] [PMID: 16552916]

[67] Yearley S. What does science mean in the 'public understanding of science. In: Dierkes M, von Grote C, Eds. Between Understanding and Trust: The Public, Science and Technology. Amsterdam: Harwood 2000; pp. 151-64.

[68] Gaskell G, Gottweis H, Starkbaum J, et al. Publics and biobanks: Pan-European diversity and the challenge of responsible innovation. Eur J Hum Genet 2013; 21(1): 14-20. [http://dx.doi.org/10.1038/ejhg.2012.104] [PMID: 22669414]

[69] Gamero J-J, Romero JL, Peralta JL, Corte-Real F, Guillén M, Anjos MJ. A study of Spanish attitudes regarding the custody and use of forensic DNA databases. Forensic Sci Int Genet 2008; 2(2): 138-49. [ i) The questionnaire is provided as supplementary material. ii) Thanks are due to the attorney Monica Galasso for her help in correctly understanding the legal norms. iii Group means are reported in brackets.]. [http://dx.doi.org/10.1016/j.fsigen.2007.10.201] [PMID: 19083809]

\section{(C) 2017 Pivetti et al.}

This is an open access article distributed under the terms of the Creative Commons Attribution 4.0 International Public License (CC-BY 4.0), a copy of which is available at: (https://creativecommons.org/licenses/by/4.0/legalcode). This license permits unrestricted use, distribution, and reproduction in any medium, provided the original author and source are credited. 